STUDIA UKRAINICA POSNANIENSIA, vol. II: 2014, pp. 113-122.

ISBN 978-83-936654-5-7. ISSN 2300-4754.

\title{
POLSKOŚĆ, UKRAIŃSKOŚĆ, UNIWERSALIZM W TWÓRCZOŚCI JAROSŁAWA IWASZKIEWICZA
}

\section{ALICJA MATRACKA-KOŚCIELNY}

Muzeum im. Anny i Jarosława Iwaszkiewiczów w Stawisku, Podkowa Leśna - Polska

\author{
ПОЛЬСЬКІСТЬ, УКРАЇНСЬКІСТЬ, УНІВЕРСАЛІЗМ \\ У ТВОРЧОСТІ ЯРОСЛАВА ІВАШКЕВИЧА
}

АЛІЦІЯ МАТРАЦЬКА-КОСЬЦЕЛЬНИ

Музей ім. Анни і Ярослава Івашкевичів у Ставиську, Подкова Лєсьна - Польща

АНОТАЦІЯ. У статті розглянуто постать Ярослава Івашкевича - одного з найвизначніших польських письменників XX століття, народженого в 1894 році у Кальнику в Україні. Українське коріння, інспірації, особлива вразливість на польсько-українські взаємини значною мірою вплинули на безперечний універсалізм його письменницьких досягнень.

\section{POLAND, UKRAINE, UNIVERSALITY IN THE WORKS OF JAROSŁAW IWASZKIEWICZ}

\section{ALICJA MATRACKA-KOŚCIELNY}

Museum of Anna and Jarosław Iwaszkiewicz in Stawisko, Podkowa Lesna - Poland

ABSTRACT. The paper presents Jarosław Iwaszkiewicz, one of the greatest Polish writers of the $20^{\text {th }}$ century, born in 1894 in Kalnik in Ukraine. Ukrainian roots, influences, particular sensitivity to the Polish-Ukrainian relations significantly influenced the unquestionable universality of his works.

Jarosław Iwaszkiewicz nie mógł pojawić się znikąd. Zrodziła go polsko-ukraińska kultura, rozwijająca się na przestrzeni wieków na naszej ziemi [...] Ukraina to jego ojczyzna, to ona go urodziła i wychowała jako twórcę ${ }^{1}$.

$\mathrm{T}$ wierdzenie znanego ukraińskiego pisarza i thumacza Dmytra Pawłyczki, autora wielu przekładów dzieł Jarosława Iwaszkiewicza, zasłużonego działacza opozycji demokratycznej, przyjaciela Iwaszkiewicza, posłużyło jako motto, wstęp do przedstawienia tematu określonego w tytule artykułu.

Twórczość urodzonego w 1894 r., w Kalniku, w Winnickim obwodzie - jednego z najwybitniejszych pisarzy polskich, w znaczącym stopniu kształtowały i determinowały te momenty i fazy jego życiorysu, które wiązały się z ukraińskim pocho-

${ }^{1}$ D. P a w 1 y c z k o, Jarosław Iwaszkiewicz i Ukraina, [w:] Miejsce Iwaszkiewicza, Stawisko. Almanach Iwaszkiewiczowski, t. 1, Podkowa Leśna 1994, s. 212-216. 
dzeniem i dziedzictwem. Można zaryzykować twierdzenie, że europejskość, niekwestionowany uniwersalizm pisarskiego dorobku Jarosława Iwaszkiewicza miałby całkiem inny wymiar i charakter, gdyby nie jego szczególna wrażliwość na polsko-ukraińskie relacje, oddziaływania, inspiracje.

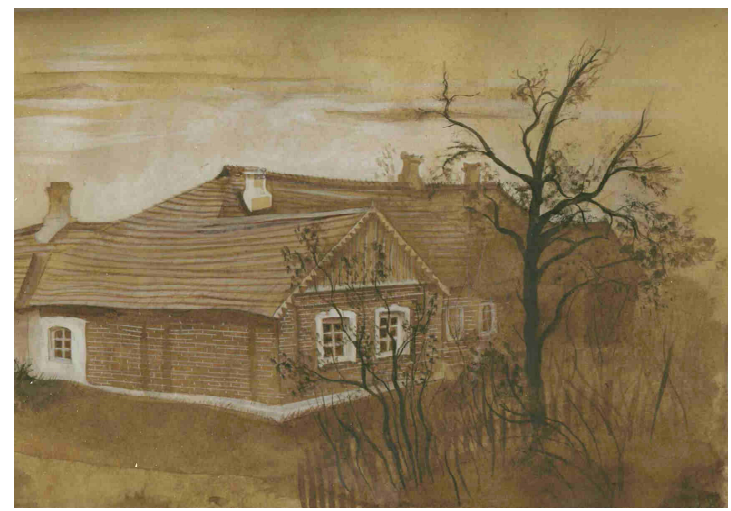

Janina Konarska, dom w Kalniku, ok.1930, ze zbiorów Muzeum w Stawisku

Jarosław Iwaszkiewicz miał pełną świadomość, że współwystępowanie, sploty doświadczeń ukraińskich i polskich czynią jego życie innym, „dziwnym”, ale z pewnością bogatszym: „Tak się splatają współczesność i przeszłość, dokonania przemysłowe i literackie, pejzaż ukraiński i artyści polscy w tym dziwnym potoku, jaki nazywamy życiem" ${ }^{2}$.

Co znaczy Ukraina i ukraińskość dla Jarosława Iwaszkiewicza?

Odpowiedź na to zasadnicze pytanie jest zarazem wskazaniem najbardziej charakterystycznych aspektów, polsko-ukraińskich relacji i inspiracji w jego twórczości.

I. Ukraina to dla Jarosława Iwaszkiewicza kraj urodzenia, to ziemia, na której przyszedł na świat, która kojarzy mu się przez całe życie z ogromnymi przestrzeniami, bezkresnymi stepami, niezwykłą przyrodą, zapachem żyznych pól, wspomnieniami baśniowych krajobrazów.

Jeden z bohaterów młodzieńczego opowiadania Gody jesienne (1918) pisze o Ukrainie jako o „ziemi pogańskiej, ziemi cielesnej obfitości, ziemi ukraińskiej pełnej owoców i czarnoksięstwa”. „Cóż za cudowna ziemia” mówi o Ukrainie główny bohater powieści Księżyc wschodzi (1925).

Ukraina to wspomnienia nie tylko pejzaży, krajobrazów, ale i konkretnych miejsc pobytów - krótszych i dłuższych, wyjazdów, podróży, a także ludzi, z którymi dane było mu się zetknąć. Kalnik, Ilińce, Daszów, Elizawetgrad, Tymoszówka, Winnica, Kijów to miasteczka i miasta, z którymi był najbardziej związany; ale także Humań, Żytomierz, Biała Cerkiew, Odessa.

${ }^{2}$ J. S z c z e r b a k, Jarostaw Iwaszkiewicz w Kijowie, [w:] Jarostaw Iwaszkiewicz i Ukraina, pod red. R. Papieskiego, Podkowa Leśna 2011, s. 230. 
Wielokulturowość jest charakterystyczną cechą tych miejsc. Iwaszkiewicz doświadcza jej w sposób zupełnie naturalny, dojrzewa w środowisku nie tylko Polaków i Ukraińców, ale także Rosjan, Żydów, Ormian, co ma ogromny wpływ na kształtowanie się jego stosunku do świata, zrozumienia i tolerancji wobec innych, a zatem wykształca i umacnia w nim poczucie bycia Europejczykiem, co ma niewątpliwy wpływ na kształtowanie się późniejszej świadomości bycia pisarzem, poetą, artystą uniwersalnym.

Sięgając do wspomnień o ludziach pisze m.in. o kucharce Wasyłynie („Ją najlepiej pamiętam Wasyłynę, była to moja wielka przyjaciółka"), o ślepym lirniku z Daszowa („U nas stawiał obok siebie na ławce miseczkę, malowaną w złote, czarne i purpurowe kwiaty i kręcił swoją lirą drewnianą, której dźwięk przypominał brzmienie klawesynu, drżącym głosem śpiewał dumy i ballady o Panu Kaniowskim i o Seritce Marysi”), a zwłaszcza o niani Dańczewskiej: „Wizyty u niani Dańczewskiej najpamiętniejsze, chata prosta z ikonami, zapach kwaśnego ciasta z wielkiej dzieży [...]. Kiedy przychodziła do nas, opowiadała bajki" ${ }^{3}$. Nierzadko we wspomnieniach tych przywołuje język ukraiński: np. charakteryzując wygląd Michaliny Taubowej - matki ciotki Szymanowskiej, cytuje słowa Żydówki z Hajsyna: „taka czorna, taka pohana, a taka szczasływa",

Fascynują go tamtejsze zwyczaje, codzienne życie z wszelkimi jego przejawami; w tym m.in. także „barszcz ukraiński z pampuszkami i czosnkiem, i hreczanyki ze skwarkami, i warenyki (pierogi z serem), które nam pod kasztanami podawano" 5 .

Rozmaite publikacje poświęcone zwyczajom świątecznym coraz częściej odwołują się do wspomnień Jarosława Iwaszkiewicza, dotyczących obrzędów wielkanocnych, które zawarł w Książce moich wspomnień (1957). Cytowane są zwłaszcza opisy przygotowywania mazurków i bab wielkanocnych: „Niezapomniany był widok, kiedy grono kobiet z poważnymi minami kołysało owe baby w obrzędowy sposób, jak gdyby od tego zależały losy świata"6. Symbolicznym podsumowaniem tego okresu jest zwierzenie po latach podczas rozmowy z Pawłyczkiem: zdarzenie z najwcześniejszego okresu swojego życia, kiedy jako niemowlę, wiezione od chrztu, znalazł się w śnieżnej zaspie wskutek chwilowego braku uwagi rodziców określił jako „zapowiedź późniejszej bliskiej więzi z ukraińską ziemią"

W Podróżach do Polski (1977) napisał:

niewątpliwie twórczość poszczególnych artystów w głęboki sposób bywa związana ze środowiskiem, z którego wyszli, z pejzażem, wśród którego żyli. Związek artysty z krajobrazem, który go ukształtował, jest głębszy, niżby to się zdawało. Dzieciństwo i młodość zaw-

${ }^{3}$ J. I w a s z k i e w i c z, Ksiqżka moich wspomnień, Poznań 2010, s. 17-18, 29-30.

${ }^{4}$ Ibidem, s. 45.

${ }^{5}$ J. I w a s z k i e w i c z, W Kijowie i gdzie indziej, [w:] Jarosław Iwaszkiewicz i Ukraina, op.cit., s. 221

${ }^{6}$ J. I w a s z k i e w i c z, Ksiażka moich wspomnień, op. cit., s. 25.

${ }^{7}$ D. P a w 1 y c z k o, Dwa dni z Jarosławem Iwaszkiewiczem, [w:] Jarosław Iwaszkiewicz i Ukraina, op.cit., s. 211. 
sze kładą zasadnicze piętno na cały już potem żywot - w dziełach dojrzałego twórcy raz po raz powraca nuta, która zapadła w jego serce od najwcześniejszych czasów. Odkrywa się tu na pół uświadomiona lub czasem zupełnie nieuświadomiona łączność między krajem lat dziecinnych a dojrzałym okresem twórczości ${ }^{8}$.

II. Ukraina to kraj pierwszych doznań i przeżyć artystycznych, estetycznych, pierwszych przyjaźni i miłości, dojrzewania do podejmowania pierwszych ważnych decyzji życiowych i wyborów.

W Elizawetgradzie i Kijowie uczęszcza do szkół i na uniwersytet, stawia pierwsze kroki w literaturze, marzy o karierze pianisty i kompozytora, próbuje swoich sił jako scenarzysta i aktor teatralny.

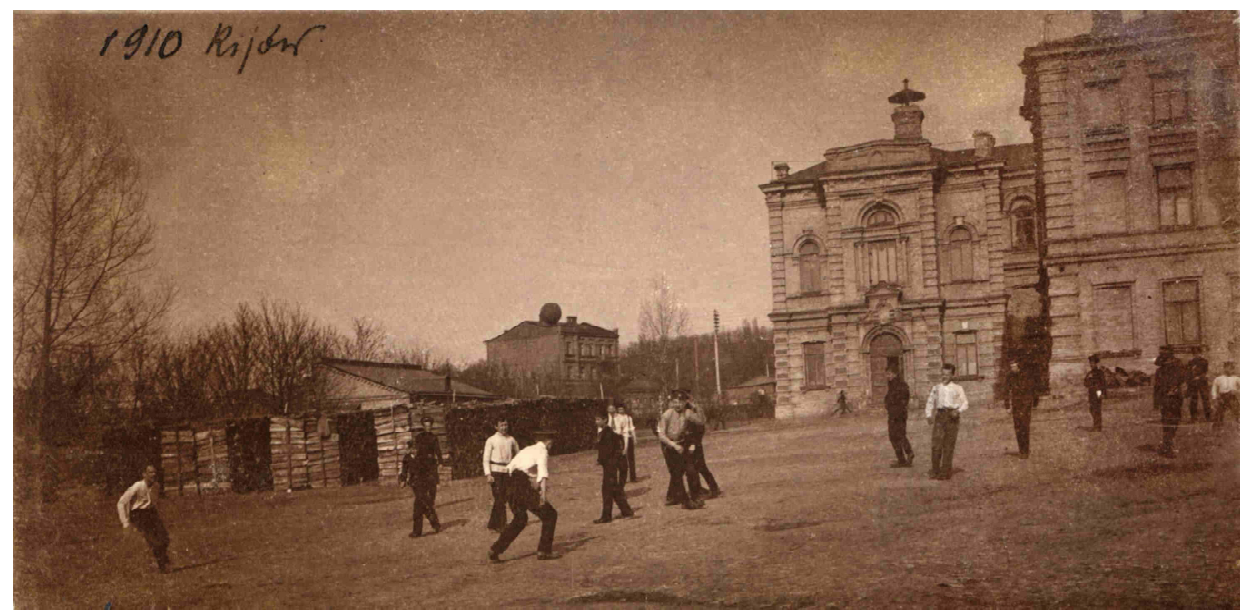

Jarosław Iwaszkiewicz na dziedzińcu gimnazjum w Kijowie, 1910, zb. Muzeum w Stawisku

Na Ukrainie rodzi się Iwaszkiewiczowski kult dla muzyki, tej najbardziej uniwersalnej, „najwyższej ze sztuk”.

Naturalna obecność muzyki w rodzinnym domu w Kalniku stanowiła owe pierwsze podstawy dla rozwijania muzycznych zainteresowań. Wśród utworów grywanych $\mathrm{i}$ słuchanych $\mathrm{w}$ kalnickim domu znajdowały się zarówno mazurki i walce Chopina (wykonawczynią była matka), jak i pieśni ukraińskie oraz „zakazane” pieśni polskie, śpiewane przez siostry Jarosława podczas „długich zmierzchów letnich i jesiennych”; „Te godziny śpiewania były moimi pierwszymi przeżyciami artystycznymi i głęboko zapadły mi w serce" - pisał w Ksiażce moich wspomnień ${ }^{9}$.

Przeżycia te ożywają po wielu latach podczas sentymentalnej podróży na Ukrainę. Książka Perty ukraińskie, kupiona przez Dmytra Pawłyczkę w księgarni w Ilińcach i podarowana Iwaszkiewiczowi wywołuje prawdziwe wzruszenie starego poety:

\footnotetext{
${ }^{8}$ J. I w a s z k i e w i c z, Podróże do Polski, Warszawa 1977, s. 40.

${ }^{9} \mathrm{~J}$. I w a s z k i e w i c z, Ksiażka moich wspomnień, op.cit., 13-14.
} 
Jest to bardzo piękna książka ze znakomitym papierem i drukiem, a zawiera duży zbiór pieśni ludowych, z których wiele znanych mi było od dzieciństwa i nawet niektóre z nich mogłem uzupełnić. Są tam pieśni Wiośnianki, kolędy, śpiewy czumackie i hajdamackie, rekruckie i żołnierskie, pieśni rodzinne i sieroce, pieśni miłosne i weselne, wybór jest bardzo duży. Razem około czterystu pieśni [...]. Bardzo mnie cieszy ta książka iliniecka. Niektóre z tych pieśni śpiewała moja ciotka Didkowska, która w przedstawieniu operetki Natałka Połtawka grała ongi w tych samych Ilińcach tytułową rolę ${ }^{10}$.

Na Ukrainie rozpoczął praktyczną naukę gry na fortepianie, najpierw w znanej szkole muzycznej Marty Neuhaus (ciotecznej siostry ojca Karola Szymanowskiego, matki Harry`ego Neuhausa), potem w Konserwatorium Kijowskim (1912-1918). Kształcił się równocześnie na wydziale prawa na tamtejszym uniwersytecie.

$\mathrm{Na}$ Ukrainie narodziły się jego marzenia o karierze kompozytora. Pierwsze próby kompozytorskie podjął zarówno samodzielnie, jak i z przyjaciółmi - Mikołajem Niedźwiedzkim i Borysem Pietrowskim. Wiosną 1911 r. stworzyli wspólną kompozycję, Wielkq sonate f-moll oraz podjęli ambitny plan skomponowania opery. Plan ten ostatecznie się nie powiódł, jednak czas spędzany z ukraińskimi przyjaciółmi skutkował nie tylko realizacjami marzeń artystycznych, wspólnym muzykowaniem, ale także dyskusjami o literaturze i sztuce.

Najistotniejsze znaczenie dla intelektualnego i artystycznego rozwoju (nie tylko muzycznego) młodego Jarosława Iwaszkiewicza w okresie ukraińskim miał bez wątpienia kontakt z rodziną Szymanowskich, a zwłaszcza z Karolem Szymanowskim. Matka Iwaszkiewicza była krewną Szymanowskich i w domu babki kompozytora się wychowywała. Dom Szymanowskich w Tymoszówce był swoistym oknem na świat, gdzie wszyscy z upodobaniem nie tylko muzykowali, ale także toczyli ożywione dyskusje na tematy sztuki i filozofii. U Szymanowskich miało miejsce pierwsze zetknięcie młodego Iwaszkiewicza z takimi pozycjami światowej literatury, jak Narodziny tragedii Nitschego, Rozmowy z Goethem Eckermanna, dziełami Żeromskiego. Tutaj wiele godzin spędzano nad studiowaniem partytur kompozytorów uważanych za przełomowych $\mathrm{w}$ dziejach europejskiej i światowej muzyki, tj. Ryszarda Wagnera, Gustawa Mahlera, Hugo Wolffa, Ryszarda Straussa, Igora Strawińskiego.

${ }^{10}$ J. I w a s z k i e w i c z, Ksiażki przywiezione z Ukrainy, [w:] Jarosław Iwaszkiewicz i Ukraina, op. cit., s. 227-228. 


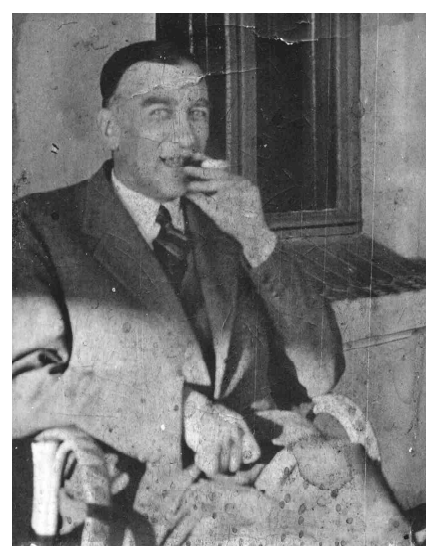

Karol Szymanowski na Stawisku, 1934, zb. Muzeum w Stawisku

W ukraińskim etapie życia Iwaszkiewicz ostatecznie zdecydował o swojej przyszłości jako artysty. Pod wpływem Karola Szymanowskiego porzucił marzenia o karierze kompozytora; dzięki Karolowi Szymanowskiemu utwierdził się jednocześnie w przekonaniu o posiadaniu talentu literackiego, nad którym warto pracować, który należy rozwijać. Pierwsza próba poetycka, wiersz Lilith, opublikowany w kijowskim czasopiśmie „Pióro” (powstały równocześnie z poematem Lilith na dwa fortepiany), zaowocowała w niedalekiej przyszłości zbiorem Oktostychy, zaliczanym do jednych z najlepszych wierszy J. Iwaszkiewicza, po lekturze których Szymanowski napisał: „To jest właśnie ten brak dyletantyzmu, «improwizowania», pewnej ręki w metier, które tak w Tobie cenię"11.

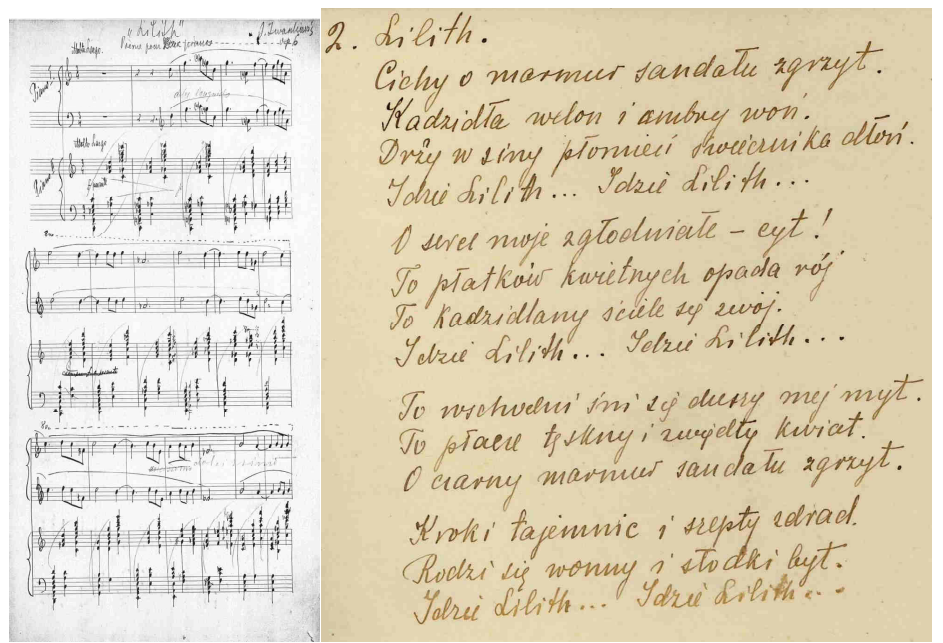

Jarosław Iwaszkiewicz, fragment kompozycji Lilith oraz wiersz Lilith, 1915, rękopisy, zb. Muzeum w Stawisku

${ }^{11}$ K. S z y m a n o w s k i, Korespondencja, oprac. T. Chylińska, t. 1, Kraków 1982, s. 543. 
Warto także wspomnieć o innym doświadczeniu „czasów ukraińskich”. W Kijowie zetknął się z teatrem „Studya”, prowadzonym przez Stanisławę Wysocką. W mieszkaniu tej niezwykle utalentowanej artystki na Małej Włodzimierskiej pobierał lekcje dykcji, deklamacji, recytacji. Fascynacja teatrem spowodowała na jakiś czas porzucenie ambicji muzycznych. W Kijowie miał okazję poznać prawdziwe sławy scen teatralnych (na czele z Juliuszem Osterwą, Aleksandrem Zelwerowiczem, Józefem Węgrzynem) i najwybitniejsze dzieła scenicznej literatury (Słowackiego, Mickiewicza, Fredry, Żeromskiego, Zapolskiej, Ibsena, Maeterlincka, Moliere a). Po kilku doświadczeniach jako aktor-amator stwierdził jednak, że talentu scenicznego nie posiada - i wrócił do marzeń o karierze kompozytora i pisarza.

W 1958 r. Iwaszkiewicz napisał:

Wyjechałem z Kijowa mając 24 lata, będąc w pełni dojrzałym człowiekiem. Na Ukrainie dojrzałem też jako pisarz. Wdzięczny jestem tym latom, Kijowowi i tej ziemi, która mnie ukształtowała $^{12}$.

III. Ukraińskość to dla Jarosława Iwaszkiewicza nieustające powroty, wspomnienia, posiadające zarazem niegasnącą moc inspirowania, wzbogacania twórczych pomysłów i artystycznych dokonań.

W miarę upływu czasu Ukraina staje się dla niego coraz bardziej ziemią egzotyczna, wyjątkowa, tajemniczą, która budzi sentymentalne, czułe wspomnienia: „to cudowna kraina Gdzieś-Tam” stwierdza w wierszu Na Spasa (1925).

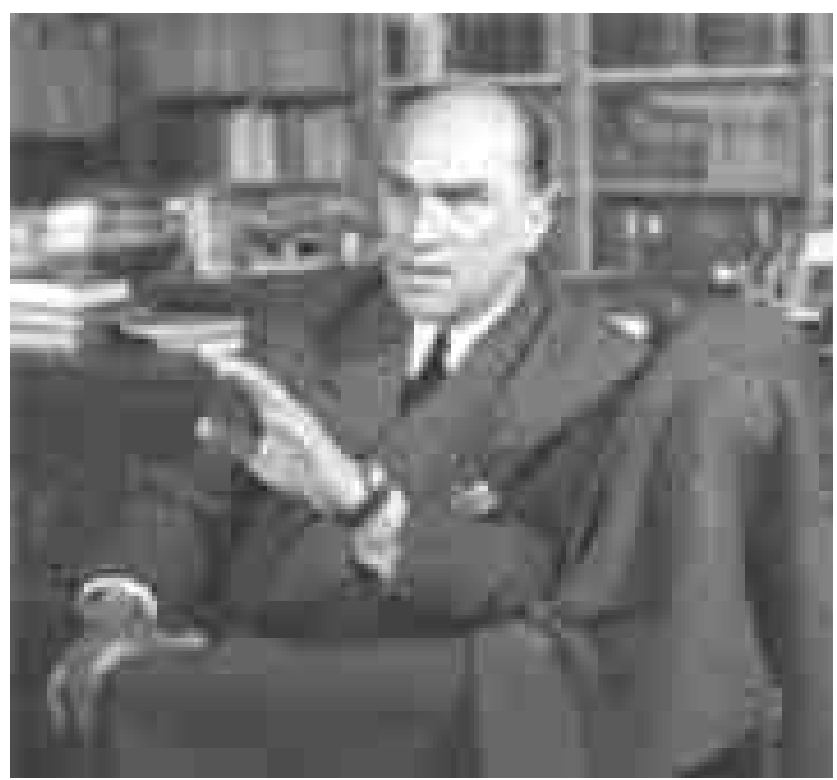

Jarosław Iwaszkiewicz w bibliotece w Stawisku, ok. 1950, zb. Muzeum w Stawisku

\footnotetext{
${ }^{12}$ Cyt. za: J. S z c z e r b a k, Jarosław Iwaszkiewicz w Kijowie, op.cit., s. 236.
} 
Polskie Mazowsze, które stało się jego miejscem na ziemi od 1918 roku do końca życia - przywodzi stale rozmaite skojarzenia z krajobrazem ukraińskim; równiny mazowieckie porównuje z naddnieprzańskimi stepami, Kijów z Warszawą. Od 1928 r. najważniejszym miejscem na ziemi dla Jarosława Iwaszkiewicza stało się Stawisko; dom, wraz z otaczającym go parkiem leśnym, znajdujący się $25 \mathrm{~km}$ od Warszawy, w którym zamieszkał wraz z żoną i córkami.

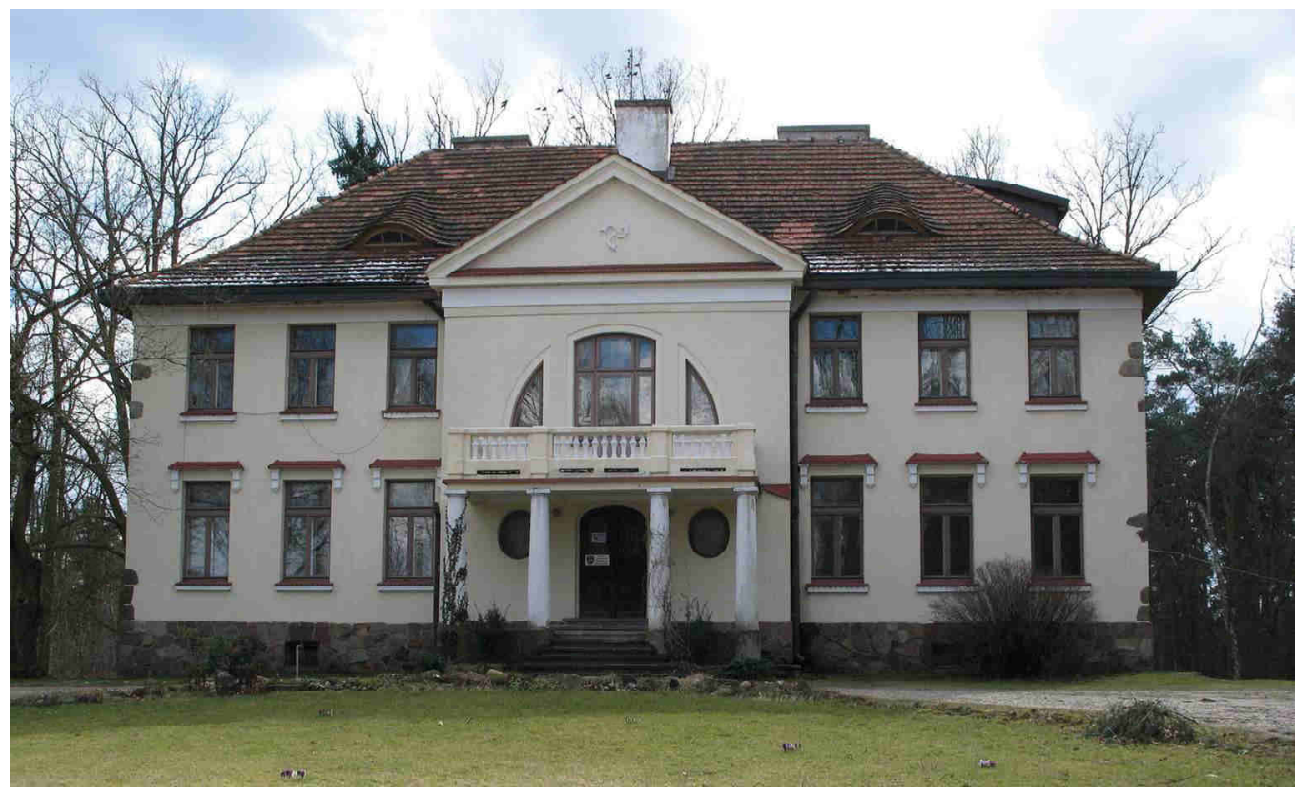

Stawisko, stan obecny, fot.: Małgorzata Zawadzka

W okresie międzywojennym, zwłaszcza po 1925 roku, Iwaszkiewicz odbywa liczne podróże po Europie, nawiązuje kontakty z wybitnymi ludźmi reprezentującymi świat kultury różnych krajów. Jego europejskość jako obywatela i pisarza nie budzi żadnych wątpliwości. Zarówno $\mathrm{w}$ poezji, jak i prozie, powstającej w tym czasie odwołuje się wielokrotnie do swojej ukraińskości. Słowami „Jak u nas na Ukrainie..." rozpoczyna wiersz pt. Wieczór późnej jesieni na polach pod Sienq ze zbioru Inne życie (1938).

Badacze twórczości Iwaszkiewicza zgodnie podkreślają, iż jego fascynacja Sycylią ma swe podłoże/źródła w ciagłym odkrywaniu podobieństw i analogii między tą włoską krainą a krajem lat dzieciństwa:

[...] tu do mnie przychodziły, odkrywane przeze mnie w dalekiej mgle polskiej pejzaże, tu widziałem oczyma wyobraźni Patrol Maksa Gierymskiego i humańską Zofijówkę, tu kończyłem Heydenreicha, Cienie, Opowiadanie z psem i Opowiadanie z kotem ${ }^{13}$.

${ }^{13}$ J. I w a s z k i e w i c z, Ksiqżka o Sycylii, Kraków 1956, s. 12. 
Bywa, że uczucie tęsknoty za ukraińską krainą trudno opanować. W wierszu z tomu Księga dnia i księga nocy (1929) pisze m.in.:

Tęsknię bardzo za błękitna dala

I za stepem równym i bezdrzewnym,

I za nieznanym mi człowiekiem tęsknie pewnym,

A tamte zorze już się dla mnie nie zapala.

Brak mi zapachu nardu i żywicy, i róży,

Jakże zabawnie zamierać w takim środowisku,

Jestem jak mrówka w zasypiającym na zimę mrowisku;

Jakże mnie ta Warszawa nuży.

(coraz rzadziej chodzę do teatru...) $)^{14}$.

Na Sycylii pisze wiersz pt. Koroniarz (zb. Xenie i elegie,1970):

\author{
Litwo ojczyzno moja \\ nie pamiętam Ciebie \\ nie tęsknię do twoich \\ świerzopów gryk i dzięcielin \\ Tęsknię do równiny mazowieckiej \\ nie szerokiej \\ podzielonej \\ to drzewkiem to domkiem \\ to szlabanami \\ [..................] \\ kiedy mieszkatem na Podolu \\ mówiliśmy: ci koroniarze \\ jedzq obrzydliwe rzeczy \\ kwaśne mleko z kartoflami \\ Nigdy nie myślatem, że będę koroniarzem ${ }^{15}$.
}

Sycylijskie miasteczko Monreale - ni stąd, ni zowąd, jak sam przyznaje, nasuwa mu skojarzenia z ukraińskim Daszowem. W Ksiqżce o Sycylii (1956) zamieszcza następujący fragment:

I wreszcie przypominam sobie Daszów, dokąa w dzieciństwie jeździłem na odpusty i jarmarki. Nic tutaj dosłownie Daszowa nie przypomina - może trochę koloryt i ożywienie południowej ludności - a jednak cały nastrój tego miasteczka jest jakiś taki, że mimo woli, zamiast katedrą i klasztorem, wyobraźnia zajmuje się tamtymi, od dawna zgasłymi obrazami [...] przypominają mi się mury pałacu daszowskiego, stara cerkiewka drewniana z pięciu wieżyczkami i kremowego koloru domy, gdzie się wówczas mieściły kramiki żydowskie ${ }^{16}$.

Reasumując: uniwersalizm twórczości Jarosława Iwaszkiewicza, jego miejsce w kulturze europejskiej można, a właściwie należy widzieć i oceniać z dwojakiej

\footnotetext{
${ }^{14}$ J. I w a s z k i e w i c z, Wiersze, t. I, Warszawa 1977, s. 208.

${ }^{15}$ Ibidem, t. II, s. 418.

${ }^{16} \mathrm{~J}$. I w a s z k i e w i c z, Ksiażka o Sycylii, op. cit., s. 12.
} 
perspektywy - ukraińskich i polskich korzeni, uwarunkowań, inspiracji. Dialog ukraińskości i polskości stanowi o niekwestionowanych walorach uniwersalnych tego pisarstwa.

Najbardziej wymownym i dzisiaj wręcz symbolicznym potwierdzeniem tej tezy są słowa Dmytra Pawłyczki:

Jeśli uważamy - nie bez podstaw - Gogola za pisarza ukraińskiego, to do tego miana nie mniej praw ma Iwaszkiewicz. On właśnie ukazał nam, Ukraińcom, naszą ziemię i historię od tej strony, z której były widoczne tylko dla niego. Ale panorama jego Ukrainy jest również naszą Ukrainą. Przy pomocy Iwaszkiewicza poznaliśmy siebie jako czumacy i rolnicy, wędrowni filozofowie i marzyciele. Ale być może najważniejsze, co o nas powiedział - to to, że jesteśmy Europejczykami ${ }^{17}$.

Temat ukraińskości i polskości Jarosława Iwaszkiewicza został w niniejszym tekście zaledwie zarysowany. Jest to problematyka szczególnie ważna i interesująca, która z pewnością będzie przedmiotem bardziej wnikliwych badań i interpretacji.

${ }^{17}$ D. P a w $ł$ y c z k o, Jarostaw Iwaszkiewicz i Ukraina, op. cit., s. 216. 